\title{
Article \\ Comparing Exergy Analysis and Physical Optimum Method Regarding an Induction Furnace
}

\author{
Paula Marlene Wenzel ${ }^{1, * \mathbb{C}}$, Peter Radgen ${ }^{1} \mathbb{D}$ and Jan Westermeyer ${ }^{2}$ \\ 1 Institute of Energy Economics and Rational Energy Use (IER), University of Stuttgart, 70565 Stuttgart, \\ Germany; peter.radgen@ier.uni-stuttgart.de \\ 2 Cuno-Berufskolleg I, 58095 Hagen, Germany; westermeyerj@cuno1.de \\ * Correspondence: paula.wenzel@ier.uni-stuttgart.de; Tel.: +49-711-685-87814
}

Citation: Wenzel, P.M.; Radgen, P.; Westermeyer, J. Comparing Exergy Analysis and Physical Optimum Method Regarding an Induction Furnace. Energies 2021, 14, 1621. https://doi.org/10.3390/en14061621

Academic Editor: Marilena Musto

Received: 17 February 2021

Accepted: 11 March 2021

Published: 15 March 2021

Publisher's Note: MDPI stays neutral with regard to jurisdictional claims in published maps and institutional affiliations.

Copyright: (c) 2021 by the authors. Licensee MDPI, Basel, Switzerland. This article is an open access article distributed under the terms and conditions of the Creative Commons Attribution (CC BY) license (https:// creativecommons.org/licenses/by/ $4.0 /)$.

\begin{abstract}
In order to achieve energy and climate goals, energy and resource efficiency are considered a key measure. Limit-value-oriented methods such as the exergy analysis and the physical optimum method are used to show the limits of efficiency improvement. In this context, the physical optimum represents the theoretical ideal reference process. Despite their similarities, no comprehensive comparison to the exergy analysis has been carried out yet. Thus, the purpose of this study is to close this gap by examining differences and intersections using the example of an induction furnace. The minimum energy input according to the physical optimum method is $1327 \mathrm{MJ} / \mathrm{t}$ whereas the exergy of the melting product is $1393 \mathrm{MJ} / \mathrm{t}$, depending on transit flows taken into account. The exergy analysis extends considerably beyond the physical optimum method in terms of the complexity and accuracy of the assessment of material flows by using exergy units. The exergy analysis makes clear which exergy is linked to the losses and thus reveals the potential for coupling processes. This results in different areas of application for the two methods.
\end{abstract}

Keywords: exergy analysis; physical optimum; PhO method; method comparison; induction furnace; efficiency; melting; iron

\section{Introduction}

Regarding the Paris Climate Conference in 2015, limited resources and increasing demand require an increase in resource efficiency, in addition to sufficiency, improved recycling management, and the use of renewable energies. Until now, improvements through efficiency measures have predominantly been measured by the actual state as the benchmark in accordance with existing standards and guidelines. However, these conventional indicators have the disadvantage that new reference points repeatedly emerge. In addition, comparability between different plants and processes is limited due to these different reference points. Furthermore, the limitation of efficiency improvements does not become clear when using conventional efficiency evaluation methods. However, this is necessary in order to estimate the contribution potential of efficiency improvement reducing resource consumption, and achieving energy and climate targets.

The physical optimum ( $\mathrm{PhO}$ ) method is an alternative assessment method to conventional methods for the consistent analysis of processes and technologies on the basis of the physical limit value. Primarily based on three dissertations [1-3], there is a draft of a guideline of the German Association of Engineers (VDI) that describes the PhO as the ultimate, unchangeable reference point [4]. The PhO is defined as the theoretically optimal reference process under physical, biological, and chemical boundary conditions [1] (p. 32).

In contrast, the exergy analysis was developed several decades ago and serves, similar to the PhO method, to show the theoretical limits of efficiency improvement, among other things. To what extent the two methods are related has not yet been investigated in detail.

The minimum energy input for melting iron using an induction furnace is already conventionally used as a benchmark and energy and material flows can both be relevant; 
the induction furnace provides a suitable example. Hence, this study aims to compare the two methods using the example of an induction furnace. Differences and intersections between exergy analysis and the $\mathrm{PhO}$ method are shown by this example. On this basis, the aim of the study is to show the overall relations and to identify important characteristics for the areas in which each method is applied.

\section{Materials and Methods}

The exergy analysis and the PhO method are described in Sections 2.1 and 2.2, respectively. Moreover, Section 2.3 contains the technical data and the assumptions made for analyzing the induction furnace as an example process.

\subsection{Exergy Analysis}

Exergy is "the amount of work obtainable when some matter is brought to a state of thermodynamic equilibrium with the common components of the natural surroundings by means of reversible processes, involving interaction only with the abovementioned components of nature" [5]. Accordingly, anergy A is defined as the difference between energy and exergy. Applying the exergy analysis, in the first step, the exergy flows are calculated in accordance with the laws of thermodynamics. In contrast to electrical and mechanical energy, which consists of $100 \%$ exergy, the exergy of heat corresponds to the product of heat quantity and the Carnot factor $\eta_{c}$ (cf. Table 1 ). The physical exergy $B_{p h}$ is calculated using the difference of enthalpy $H$, the temperature $T$, the pressure $p$, and the entropy $S$ of the material in relation to the ambient parameters as follows:

$$
B_{p h}=H_{p h}(p, T)-H_{a m b}\left(p_{a m b}, T_{a m b}\right)-T_{a m b}\left(S_{p h}(p, T)-S_{a m b}\left(p_{a m b}, T_{a m b}\right)\right) .
$$

In the case of ideal gases and reversible isobaric change of state from $T_{1}$ to $T_{2}$, the physical exergy can be calculated as a function of the specific heat capacity $c_{p}$. The derivation can be obtained from, e.g., Gutowski et al. [6].

$$
B_{p h}=c_{p}\left(\left(T_{2}-T_{1}\right)-T_{a m b} \ln \frac{T_{2}}{T_{1}}\right) .
$$

The calculation of the chemical exergy $B_{c h}$ of material flows is more complex and depends on the environmental model. For standard chemical reactions, the reactive exergy is listed in tables. The standard chemical exergy of material flows without chemical reactions is tabulated as well. For this study, the model describing the conventional mean concentrations of the reference species in the atmospheric air and the material data on chemical exergy are obtained from [7]. These are listed in Table 1 in Appendix A. Table 1 provides an overview of the exergy $B$ of different forms of energy and its calculation. 
Table 1. Exergy percentage and exergy calculation of different forms of energy, based on [8].

\begin{tabular}{|c|c|c|c|c|}
\hline \multicolumn{3}{|c|}{ Energy Components } & Exergy Percentage ${ }^{1}$ & Exergy Calculation \\
\hline \multirow{3}{*}{$\begin{array}{l}\text { Material- } \\
\text { free }\end{array}$} & \multicolumn{2}{|c|}{ Electrical energy $W_{e l}$} & $100 \%$ & $B_{e l}=W_{e l}$ \\
\hline & \multicolumn{2}{|c|}{$\begin{array}{c}\text { Magnetic energy } W_{\text {mag }} \\
\text { Mechanical energy } W_{\text {mech }}\end{array}$} & $\begin{array}{l}100 \% \\
100 \%\end{array}$ & $\begin{aligned} B_{\text {mag }} & =W_{\text {mag }} \\
B_{\text {mech }} & =W_{\text {mech }}\end{aligned}$ \\
\hline & Therm. & $\begin{array}{c}\text { Heat } Q \\
\text { Ambient heat } Q_{a m b}\end{array}$ & $\begin{array}{c}0 \% \leq \frac{B}{Q}<100 \% \\
0 \% \text { (100\% anergy) }\end{array}$ & $\begin{array}{c}B_{Q}=Q \cdot \frac{T-T_{a m b}}{T}= \\
Q \cdot \eta_{c} \\
B_{0}=0\end{array}$ \\
\hline \multirow{3}{*}{$\begin{array}{l}\text { Stream of } \\
\text { substance }\end{array}$} & \multicolumn{2}{|c|}{$\begin{array}{l}\text { Kinetic energy } E_{k i n} \\
\text { Potential energy } E_{p o t}\end{array}$} & $\begin{array}{c}100 \% \\
100 \% \\
0 \% \leq \frac{B}{H}<100 \%\end{array}$ & $\begin{array}{c}B_{k i n}=\frac{1}{2} m\left(v^{2}-v_{a m b}^{2}\right) \\
B_{p o t}=m g\left(z-z_{a m b}\right) \\
B_{p h}=H_{p h}-H_{a m b}- \\
T_{a m b}\left(S_{p h}-S_{a m b}\right)\end{array}$ \\
\hline & \multirow[t]{2}{*}{ Chemical } & $\begin{array}{c}\text { Non-reactive } \\
\text { (standard chemical } \\
\text { exergy) }\end{array}$ & $0 \% \leq \frac{B}{H}<100 \%$ & $\begin{array}{l}\text { Tabulated for standard } \\
\text { conditions [7] }\end{array}$ \\
\hline & & $\begin{array}{l}\text { Reactive } \\
\text { Mixing }\end{array}$ & $0 \% \leq \frac{B}{H}<100 \%$ & $\begin{array}{c}\text { Tabulated for reference } \\
\text { reactions }[7] \\
B_{\text {mix }}=R T_{u} \sum y_{i} \ln y_{i}\end{array}$ \\
\hline
\end{tabular}

${ }_{1}^{1}$ with reference to the state parameters and the commonly appearing components of the environment.

Regarding the output flows, the exergy analysis distinguishes between exergy $B_{P}$ associated with the product, internal exergy loss (exergy destruction) $B_{D}$, and external exergy losses $B_{L}$ associated with waste streams or by-products. Thus, the irreversibility within the system boundary $\left(B_{D}\right)$ and potentially usable exergy losses $\left(B_{L}\right)$ become clear. Transit exergy as the exergy passing spatially through the system but not involved in the process might be of significant importance in some cases and has to be considered [9] (p. 29). Based on the exergy balance, the exergetic efficiency $\eta_{B}$ represents the ratio of the useful exergetic effect $\dot{B}_{P}$ to the supplied exergy flow $\dot{B}_{i n}$.

$$
\eta_{B}=\frac{\dot{B}_{P}}{\dot{B}_{\text {in }}}=\frac{\dot{B}_{\text {in }}-\dot{B}_{L}+\dot{B}_{D}}{\dot{B}_{\text {in }}}=1-\frac{\dot{B}_{L}+\dot{B}_{D}}{\dot{B}_{\text {in }}} .
$$

\subsection{Physical Optimum (PhO) Method}

Contrary to the exergy analysis, the PhO method focuses on the description of the $\mathrm{PhO}$, the theoretical ideal reference process, rather than the exergetic analysis of a real, non-ideal plant. In this study, the PhO method is applied according to [1,2,4].

Volta [1] (p. 33) defines the $\mathrm{PhO}$ as the theoretically ideal reference process according to scientific laws. This refers to the physical, chemical, and biological limitations. For a technical process that generates a defined utility, the corresponding PhO can be described. The respective reference process requires a certain minimum amount of energy and resources, which represents the limit value for that technical process. Due to technical imperfections, e.g., heat losses, the $\mathrm{PhO}$ is not feasible in practice. The new VDI guideline draft [4] proposes to define the $\mathrm{PhO}$ as the physically based reference value, which can be energy, exergy, and a material flow. In this study, we are using the definition of the $\mathrm{PhO}$ according to Volta [1].

For balancing the temporal and spatial system boundary, the framework conditions and the utility definition must be precisely specified, which is crucial for the following analysis. If necessary, the system should be broken down into subsystems, so that adequate reference processes can be used for the evaluation [1] (p. 35). According to the laws of physics, the PhO is calculated. Applying the energy or resource balance for the PhO method, a distinction is made between real expenditure, losses, and minimum expenditure at $\mathrm{PhO}$ for the defined utility. Where applicable, the energy or material expenditure for coupling processes inside and outside the balance area is given extra consideration. The PhO factor as the central indicator for the $\mathrm{PhO}$ method is defined as the ratio of real expenditure $\mathrm{C}$ of the investigated process to the $\mathrm{PhO}$ minimum expenditure $C_{P h O}$. An amount of resources 
is given the symbol $C$ in this study, because it can be energy or material, among others. The $\mathrm{PhO}$ factor demonstrates the additional expenditure compared to the PhO. It is defined as

$$
F_{P h O}=\frac{\text { real resource input }}{\text { corresponding limit value }}=\frac{C}{C_{P h O}} \geq 1 .
$$

To determine the $\mathrm{PhO}$ factor $F_{P h O}$, a $\mathrm{PhO}$ minimum expenditure greater than zero is required. Furthermore, to compare a certain process with the best available technology, the PhO factor of both systems can be calculated to always keep the reference to the ultimate PhO.

Moreover, Keichel [2] distinguishes between demand and consumption perspectives, which describes either a minimum expenditure for a fixed demand for a certain utility or a maximum utility of a fixed available expenditure (consumption), respectively. For processes with minimum demand for the defined utility, the demand perspective is appropriate. Thus, the consumption perspective is not further considered in this study.

\subsection{Data and Assumptions}

To compare the two methods, they are applied separately to the same case example of a medium-frequency furnace. At first, the system boundary and the data are described.

\subsubsection{System Boundaries and Utility Definition}

The utility to be generated by an induction furnace is at this point defined as the liquid melt having a certain molecular structure and temperature $T_{2}$. These parameters are determined by the quality requirements regarding mechanical and metallurgical properties, which the product must meet in solid state when leaving the foundry. This case study looks at spheroidal graphite cast iron (SG iron). The required output temperature $T_{2}$ is $1773 \mathrm{~K}$, which is due to the maximum oxygen loading [10] (p. 128).

A furnace transformer, a frequency converter, and a capacitor are installed in front of the induction coil, as illustrated in Figure 1. The balance area of the induction furnace includes the power supply chain from the transformer and the induction coil and the furnace crucible. The peripheral processes, such as cooling systems, melting processors, charging devices, and exhaust systems are located outside the balance area. Thus, the supply of these components with electrical energy is not taken into account. The system boundary is defined in such a way that the ambient conditions prevail at the boundary and exergy only leaves the system substance-bound. This means that there are no pressure and temperature gradients outside the balance area, which are caused by the induction furnace and not emitted as quantifiable exergy loss bound to a substance flow, e.g., coolant, except the electrical exergy input. Due to the exhaust hood, the air is drawn through the system and heated by waste heat. The basis for this study is the temporal system boundary of one batch cycle from the point at which the input material enters the balance area in state 1 until it leaves in state 2 . 


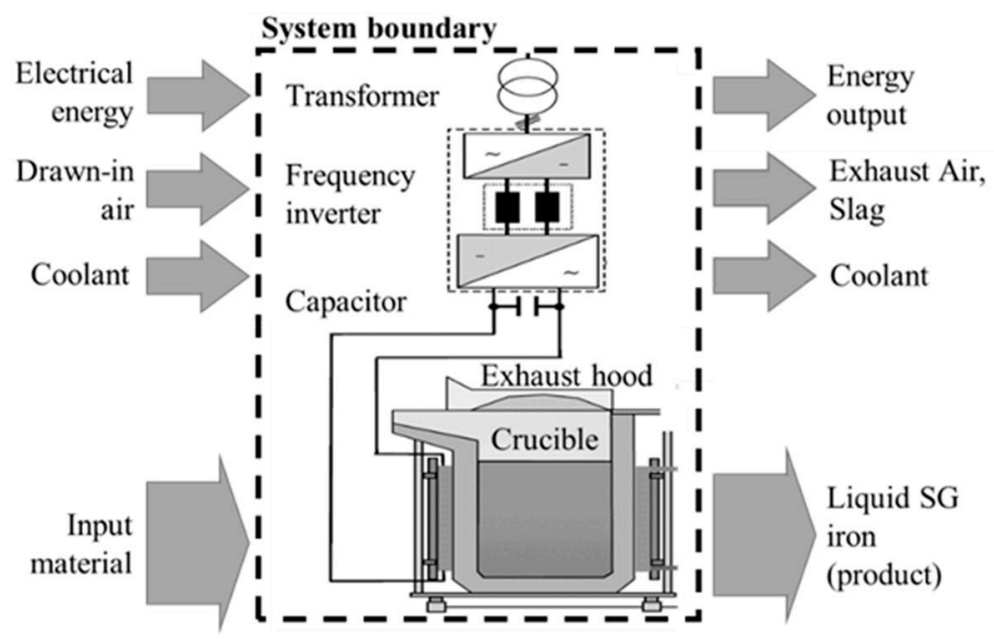

Figure 1. Process structure based on [10] (p. 22) and system boundaries for this study.

\subsubsection{General Assumptions}

The furnace under consideration is not a tandem system, although this is considered the best available technology [11]. Furthermore, a hot start is assumed for the balance, which means the crucible has the same temperature at the beginning and end of the batch cycle. A cold start could otherwise require 10\% more energy [12] (p. 9).

Some small material flows are disregarded. The manganese percentage of SG iron of about $0.1 \%$ and the sulfur percentage of less than $0.02 \%$ are neglected [13] (p. 370). The abrasion of the refractory of approx. $1.52 \mathrm{~kg} \mathrm{SiO}_{2}$ per ton and batch is also completely omitted [14] (p. 98). The examined furnace system is operated without slag formers. Instead, the furnace is left open for a while, causing the slag to cool down and the viscosity to increase for its removal [15].

With regard to the components of slag and exhaust air, only the main components are taken into account. Hence, magnesium oxide $(\mathrm{MgO})$, manganese oxide $(\mathrm{MnO})$, and iron oxide $(\mathrm{FeO})$ with a mass fraction of $1 \%$ to $6 \%$, respectively, in the slag and the exhaust air, and calcium oxide $(\mathrm{CaO})$ in the exhaust air with less than $1 \%$ are neglected [13] (p. 274).

For both analyses, the ambient condition is set to an ambient temperature $\mathrm{T}_{0}$ of $298 \mathrm{~K}$ and an ambient pressure $\mathrm{p}_{0}$ of 101,325 Pa. The material and chemical composition of the environment is determined according to [7]. The absolute humidity for the following analysis is $15 \mathrm{~g} / \mathrm{kg}_{\text {air }}$.

Potential and kinetic energy and exergy of mixing are neglected since these exergies are assumed to be significantly smaller than the other exergy flows in the system [16] (pp. 1519). With mole fractions of $0.82 \mathrm{Fe}, 0.15 \mathrm{C}$, and $0.03 \mathrm{Si}$ calculated from the mass fractions of $0.945 \mathrm{Fe}, 0.037 \mathrm{C}$, and $0.018 \mathrm{Si}[10]$, the mixing exergy amounts approx. $\mathrm{B}_{\mathrm{mix}}=\mathrm{RT}_{\mathrm{u}} \sum\left(\mathrm{y}_{\mathrm{i}} \ln \left(\mathrm{y}_{\mathrm{i}}\right)\right)$ $=8.314 \times 298 \mathrm{~K} \times(0.82 \times \ln (0.82)+0.15 \times \ln (0.15)+0.03 \times \ln (0.03))=-1.3 \mathrm{~kJ} / \mathrm{mol}$, whereas the chemical exergy amounts $376 \mathrm{~kJ} / \mathrm{mol}$ of iron, $410 \mathrm{~kJ} / \mathrm{mol}$ carbon, and $855 \mathrm{~kJ} / \mathrm{mol}$ silicon [7] (pp. 298, 300, and 304). The result is not considered for the following analysis since the calculation is an approximate simplification based on the assumption of ideal gases.

\subsubsection{Physical Input-Output Table}

The data of the considered induction furnace originates from a customer of Bosch Energy and Building Solutions $\mathrm{GmbH}$ [15]. Missing data are supplemented by a literature search, based mainly on $[10,14,17]$.

The physical input-output table (PIOT) and the literature sources of this inventory data are shown in Table 2. To produce one ton of liquid SG iron, the induction furnace under consideration consumes an average electrical energy of $2339 \mathrm{MJ}$ [15]. 
Table 2. Physical input-output table of the induction furnace melting spheroidal graphite cast iron (SG iron).

\begin{tabular}{|c|c|c|c|c|}
\hline & Parameter & Value & Ref. & Comment \\
\hline \multirow{8}{*}{ Input } & Electrical Energy & $2339 \mathrm{MJ}$ & [15] & per ton output, measured, averaged over one year (2018) \\
\hline & $\begin{array}{l}\text { Stack of Sheets } \\
\mathrm{Fe}(\alpha) \\
\mathrm{C}\end{array}$ & $\begin{array}{l}358.0 \mathrm{~kg} \\
354.4 \mathrm{~kg} \\
3.6 \mathrm{~kg}\end{array}$ & $\begin{array}{l}{[14]} \\
(\mathrm{p} .98)\end{array}$ & $\begin{array}{l}\text { 35.8\% stack of sheets of total metal input } \\
\text { Assumption: } 1 \% \text { carbon }\end{array}$ \\
\hline & $\begin{array}{l}\text { Recycled Metal } \\
\text { Fe }(\alpha) \\
\mathrm{C} \text { (graphite) } \\
\mathrm{Si}\end{array}$ & $\begin{array}{l}625.0 \mathrm{~kg} \\
590.6 \mathrm{~kg} \\
23.1 \mathrm{~kg} \\
11.2 \mathrm{~kg}\end{array}$ & $\begin{array}{l}{[14](\text { p. 98) }} \\
{[18] \text { (p. 16) }}\end{array}$ & $\begin{array}{l}24.6 \% \text { circulation, } 37.1 \% \text { cuttings } \\
94.5 \% \mathrm{Fe} \\
3.7 \% \mathrm{C} \\
1.8 \% \mathrm{Si}\end{array}$ \\
\hline & $\begin{array}{l}\text { Alloying Materials } \\
\text { C(graphite) } \\
\text { SiC (hexagonal) }\end{array}$ & $\begin{array}{l}17.1 \mathrm{~kg} \\
7.5 \mathrm{~kg} \\
9.6 \mathrm{~kg}\end{array}$ & \multirow[b]{2}{*}{ [14] (p. 98) } & \multirow{2}{*}{$\begin{array}{l}\text { calculated based on the literature data of the output materials (mass } \\
\text { conservation) and values compared and reviewed on the basis of }[14] \\
\qquad \dot{m}_{i n, X}=\dot{m}_{\text {out }, X}\end{array}$} \\
\hline & $\begin{array}{c}\text { Impurities (Sand, Rust) } \\
\mathrm{SiO}_{2} \text { (quartz) } \\
\mathrm{Al}_{2} \mathrm{O}_{3} \text { ( } \alpha \text { corrundum) } \\
\text { CaO } \\
\mathrm{Fe}_{2} \mathrm{O}_{3} \text { (hematite) }\end{array}$ & $\begin{array}{l}20.9 \mathrm{~kg} \\
11.0 \mathrm{~kg} \\
2.9 \mathrm{~kg} \\
6.5 \mathrm{~kg} \\
0.6 \mathrm{~kg}\end{array}$ & & \\
\hline & $\begin{array}{c}\text { Drawn-in Air } \\
\text { Dry Air }\end{array}$ & $\begin{array}{l}6300 \mathrm{~kg} \\
6206 \mathrm{~kg}\end{array}$ & {$[15,19]$} & 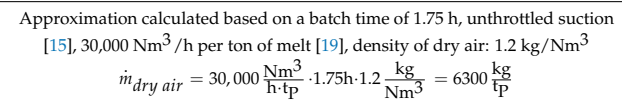 \\
\hline & $\mathrm{H}_{2} \mathrm{O}$ (gaseous) & $94.5 \mathrm{~kg}$ & & $\begin{array}{l}\text { assumption of absolute humidity of } 15 \mathrm{gH} \mathrm{H}_{2} \mathrm{O} / \mathrm{kg}_{\text {air }}, 298 \mathrm{~K}, 101,325 \mathrm{~Pa} \\
\qquad \dot{m}_{\mathrm{H} 2 \mathrm{O}}=6300 \frac{\mathrm{kg}}{\mathrm{t}_{\mathrm{air}}} \cdot 0.015 \frac{\mathrm{kg} 2 \mathrm{H} 2 \mathrm{O}}{\mathrm{kg}}=94.5 \frac{\mathrm{kg}}{\mathrm{tP}}\end{array}$ \\
\hline & $\begin{array}{c}\text { Coolant Electric } \\
\left(\mathrm{H}_{2} \mathrm{O} \text { at } 307 \mathrm{~K}[10]\right)\end{array}$ & $5005 \mathrm{~kg}$ & [10] (pp. 50-51) & 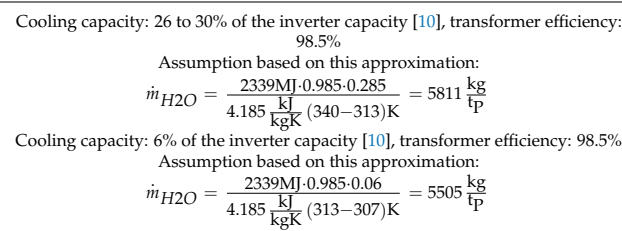 \\
\hline \multirow{5}{*}{ Output } & $\begin{array}{l}\text { Liquid SG iron at } 1873 \mathrm{~K} \\
\mathrm{Fe}(\alpha) \\
\mathrm{C} \text { (graphite) } \\
\mathrm{Si}\end{array}$ & $\begin{array}{l}1000 \mathrm{~kg} \\
945 \mathrm{~kg} \\
37 \mathrm{~kg} \\
18 \mathrm{~kg}\end{array}$ & [18] (p. 16) & $\begin{array}{l}\text { Reference value } \\
94.5 \% \mathrm{Fe} \\
3.7 \% \mathrm{C} \\
1.8 \% \mathrm{Si}\end{array}$ \\
\hline & $\begin{array}{c}\text { Slag } \\
\mathrm{SiO}_{2} \text { (amorphous) } \\
\left.\mathrm{Al}_{2} \mathrm{O}_{3} \text { ( } \alpha \text { corundum }\right)\end{array}$ & $\begin{array}{l}20.0 \mathrm{~kg} \\
10.7 \mathrm{~kg} \\
6.5 \mathrm{~kg} \\
2.8 \mathrm{~kg}\end{array}$ & {$[13,19]$} & 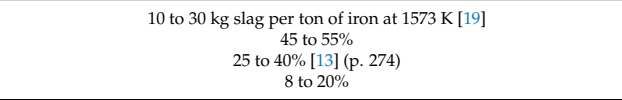 \\
\hline & $\begin{array}{c}\text { Exhaust Air } \\
\mathrm{Fe}_{2} \mathrm{O}_{3} \text { (hematatite) } \\
\mathrm{SiO}_{2} \text { (amorphous) } \\
\mathrm{C} \text { (graphite) } \\
\mathrm{Al}_{2} \mathrm{O}_{3} \text { ( ( c corundum) } \\
\text { dry air } \\
\mathrm{H}_{2} \mathrm{O} \text { (gaseous) }\end{array}$ & $\begin{array}{l}1.0 \mathrm{~kg} \\
0.6 \mathrm{~kg} \\
0.3 \mathrm{~kg} \\
0.1 \mathrm{~kg} \\
0.1 \mathrm{~kg} \\
620 \mathrm{~kg} \\
94.5 \mathrm{~kg}\end{array}$ & {$[13,20](\mathrm{p} .41)$} & $\begin{array}{l}0.06 \text { to } 1 \mathrm{~kg} \text { dust emission per ton of iron } \\
30 \text { to } 60 \% \\
\sim 25 \%[13](\mathrm{p} .274) \\
3 \text { to } 10 \% \\
3 \text { to } 10 \% \\
\text { Equals input of dry air and moisture (H2O) }\end{array}$ \\
\hline & $\begin{array}{l}\text { Coolant Inductor } \\
\text { Coolant Electric }\end{array}$ & $\begin{array}{l}5811 \mathrm{~kg} \\
5505 \mathrm{~kg}\end{array}$ & & Equals input of coolant: $\mathrm{H}_{2} \mathrm{O}$ at $340 \mathrm{~K}[10]$ (p. 51$)$ and $\mathrm{H}_{2} \mathrm{O}$ at $313 \mathrm{~K}[10]$ (p. 54$)$ \\
\hline & Energy Output & & & to be analyzed \\
\hline
\end{tabular}


For both, $\mathrm{PhO}$ analysis and exergy analysis, the enthalpy curves of the input and output material are crucial. Figure 2 shows that pure substances have an enthalpy of zero at ambient temperature ( $298 \mathrm{~K})$. In comparison, the compounds ferrosilicon ( $\mathrm{FeSi}$ ), silicon carbide $(\mathrm{SiC})$, and SG iron have a negative enthalpy value at ambient temperature, e.g., the enthalpy of SG iron is $-83 \mathrm{MJ} / \mathrm{t}$ at $298 \mathrm{~K}$ and $-1826 \mathrm{MJ} / \mathrm{t}$ for silicon carbide. Moreover, SG iron has an enthalpy of $1327 \mathrm{MJ} / \mathrm{t}$ at $1773 \mathrm{~K}$ and $1412 \mathrm{MJ} / \mathrm{t}$ at $1873 \mathrm{~K}$. The phase transitions of the substances become apparent at points of discontinuity.

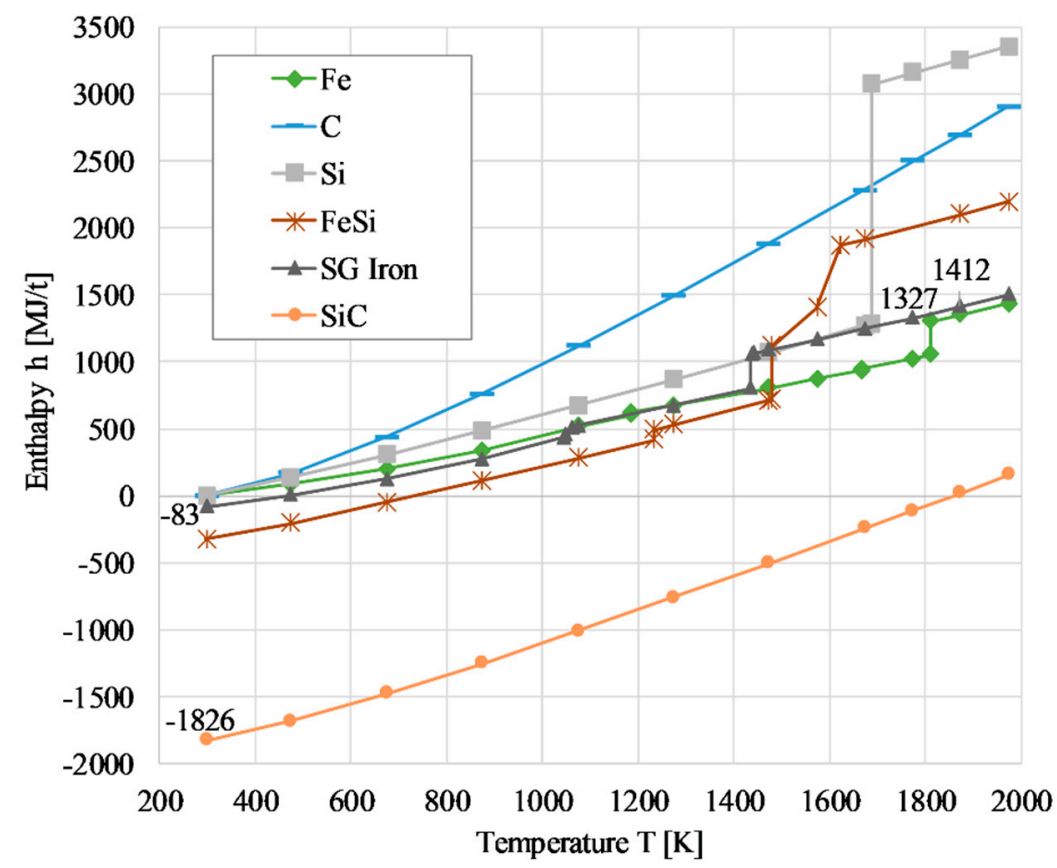

Figure 2. Enthalpy curves of carbon (C), iron (Fe), silicon ( $\mathrm{Si}$ ), ferrosilicon (FeSi), silicon carbide ( $\mathrm{SiC})$, and SG iron as a function of temperature, based on [18] (pp. 11-17).

\section{Results}

Based on the data and general assumptions in Section 2.3, this section presents the energy efficiency analysis of an induction furnace as a case study, firstly using an exergy analysis and secondly according to the PhO method. Both analyses are based on the PIOT in Table 2. The results are shown in Sections 3.1 and 3.2, respectively. On this basis, the two methods are compared in Section 3.3, which is the focus of this paper to derive differences and similarities.

\subsection{Exergy Analysis}

The exergy analysis is performed by calculating the exergy of all energy and material inputs and outputs in relation to the system boundary according to the equations in Table 1.

The electrical energy of about $2339 \mathrm{MJ} / \mathrm{t}_{\mathrm{P}}$ is supplied to the system as substance-free exergy consisting of $100 \%$ exergy. The material input to the furnace interior enters the balance area in state 1 , which means under ambient conditions, $p_{0}$ and $T_{0}$. Thus, no physical exergy enters the balance area. In state 2 , the material to be melted is in the liquid state-also at ambient pressure $p_{0}$, though with the temperature $T_{2}$ of $1873 \mathrm{~K}$. According to Szargut et al. [7], the physical exergy of the input and output material is calculated using Equation (2), as a function of the specific heat capacities of the different substances. These are obtained from the literature $[7,21]$. Since the heat capacities are temperaturedependent and phase transitions must be taken into account, especially regarding metals, the mean specific heat capacity $\bar{c}_{p}$ of SG iron in the temperature range between $298 \mathrm{~K}$ and 
$1873 \mathrm{~K}$ is derived from the enthalpy curve shown in Figure 2 as approximate simplification. The following simplification is used for the mean heat capacity:

$$
\bar{c}_{p}=\frac{H_{2}-H_{1}}{T_{2}-T_{1}}=\frac{1412 \mathrm{MJ} / \mathrm{t}_{\mathrm{P}}-\left(-83 \mathrm{MJ} / \mathrm{t}_{\mathrm{P}}\right)}{1873.15 \mathrm{~K}-298.15 \mathrm{~K}}=0.949 \frac{\mathrm{MJ}}{\mathrm{t}_{\mathrm{P}} \mathrm{K}} .
$$

Thus, the physical exergy of the SG iron product leaving the furnace is approximately

$$
B_{p h}=0.949 \frac{\mathrm{MJ}}{\mathrm{t}_{\mathrm{P}} \mathrm{K}} \cdot\left((1873 \mathrm{~K}-298 \mathrm{~K})-298 \mathrm{~K} \cdot \ln \frac{1873 \mathrm{~K}}{298 \mathrm{~K}}\right)=975 \frac{\mathrm{MJ}}{\mathrm{t}_{\mathrm{P}}} .
$$

The standard chemical exergy of the inputs and outputs is calculated using the tabulated values from Szargut et al. [7]. The heat capacities and the physical and chemical exergy flows are shown in Figure 3 and Table 1 in Appendix A. The term "transit-adjusted" addresses the exergy input and output of the balance area minus the transit exergy.

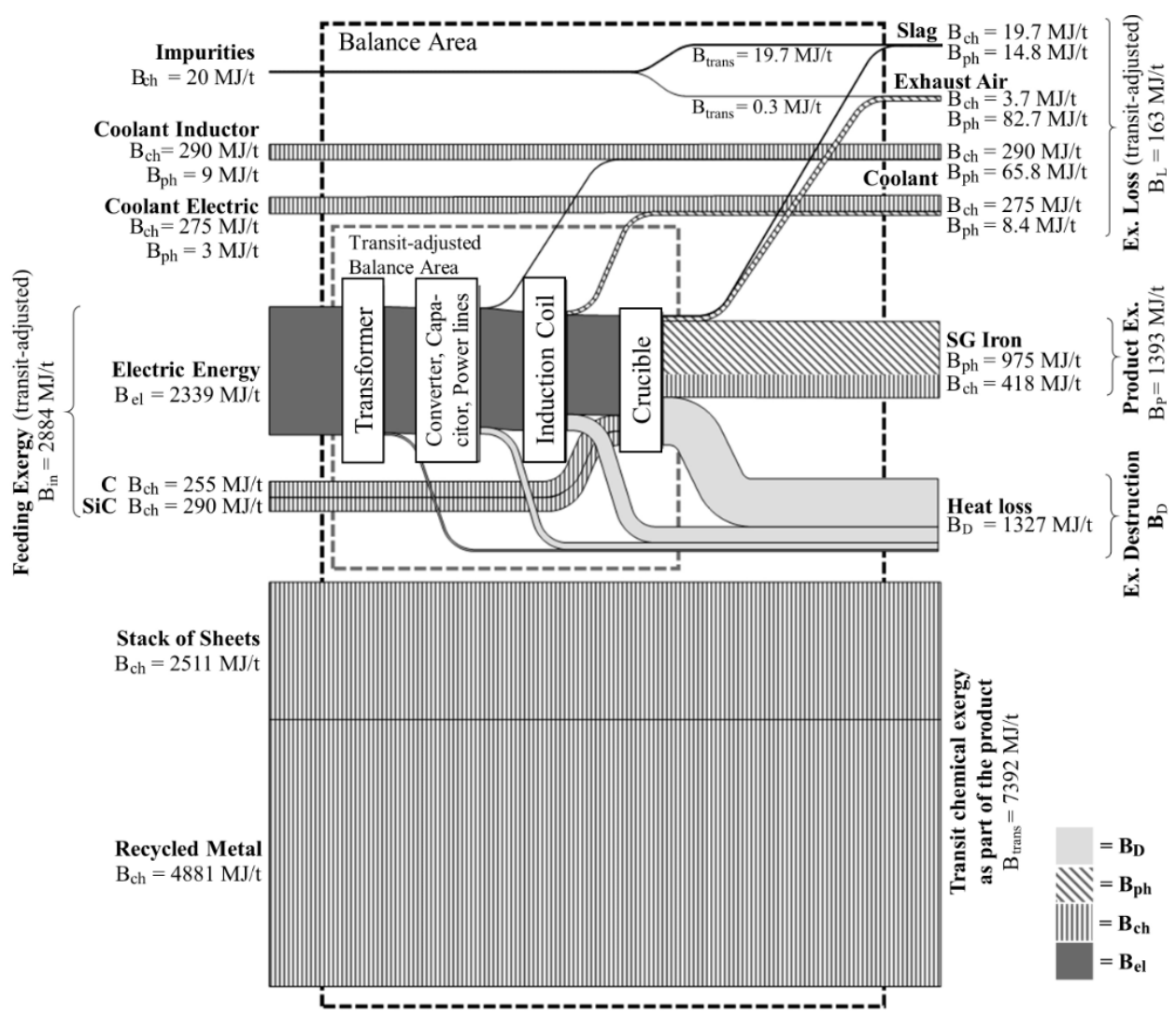

Figure 3. Sankey diagram of the exergy flows of the induction furnace melting SG iron.

The exergy of useful products $B_{P}$ is the SG iron-bound exergy output without the transit exergy. The exergy utility is composed of the physical and chemical exergy of the product. The melt has a temperature $T_{2}$ of about $1873 \mathrm{~K}$ when it leaves the balance area.

The exergy loss of the induction furnace is the material-bound exergy of the exhaust air $\left(86.1 \mathrm{MJ} / \mathrm{t}_{\mathrm{P}}\right)$, the coolant $\left(62.2 \mathrm{MJ} / \mathrm{t}_{\mathrm{P}}\right)$, and the slag $\left(14.9 \mathrm{MJ} / \mathrm{t}_{\mathrm{P}}\right)$. It amounts to $163 \mathrm{MJ} / \mathrm{t}_{\mathrm{P}}$ in total without the transit flows. The exergy loss is calculated as the sum of the physical and chemical exergy of the slag, exhaust air, and coolant minus their respective transit exergy from coolant and impurities. For example, for exhaust air, the exergy loss in $\mathrm{MJ} / \mathrm{t}$ is $3.7(\mathrm{ch})+82.7(\mathrm{ph})-0.3$ (ch, from impurities) $=86.1$. The chemical exergy of $3.4 \mathrm{MJ} / \mathrm{t}$ comes from the carbon input, which is considered as material need on the input side and material loss on the output side-in contrast to the material input of impurities, which are neither considered as a demand nor as a loss. These data can be obtained from Table 1 in Appendix A. 
The exergy is supplied firstly by means of electrical energy and secondly as exergy bound in the input materials. Transit-adjusted, feeding exergy of $2889 \mathrm{MJ} / \mathrm{t}_{\mathrm{P}}$ enters the system of which $1393 \mathrm{MJ} / \mathrm{t}_{\mathrm{p}}$ leaves the system as product-bound exergy output $B_{P}$ without the transit exergy of the recycled metal and the stack of sheets. As the difference between transit-adjusted output and input exergy, the exergy destruction is $1327 \mathrm{MJ} / \mathrm{t}_{\mathrm{P}}$. Consequently, the transit-adjusted exergy efficiency $\bar{\eta}_{B}$ is $48 \%$.

Figure 3 illustrates the exergy flows of the induction furnace in a Sankey diagram. Transit flows are separated by means of an inner system boundary. The underlying data can be found in Table 1 in Appendix A.

The Sankey diagram shows that the largest quantities of exergy pass through the balance area as transit flows. This is due to the fact that all chemical exergies are taken into account, even if they are not involved in the process. The recycled metal and the stack of sheets are liquefied in the induction furnace but only change their chemical structure insignificantly. Hence, only the physical exergy is considered within the transit-adjusted balance area in this case.

In addition to efficiency measures for reducing heat losses, the exergy balance reveals a theoretical potential of approximately $163 \mathrm{MJ} / \mathrm{t}_{\mathrm{P}}$ for increasing efficiency through the implementation of coupling processes. This corresponds to the unused exergy loss that is due to exhaust gas, slag, and coolant for inductor and electric.

\subsection{PhO Method}

Contrary to exergy analysis, the starting point for the method of $\mathrm{PhO}$ is the description of the PhO as the theoretical ideal reference process. As described in Section 2.3., the utility is defined as the liquid melting material with a temperature of $1773 \mathrm{~K}$ since this temperature is sufficient for the quality requirements based on the assumption of the ideal material composition of the input materials for the PhO. The method only considers one dimension at a time, which is energy in this study.

The theoretical minimum energy input is calculated by the enthalpy differences between the input and output substances at the respective temperature levels. SG iron at $1773 \mathrm{~K}$ has an enthalpy value of $1327 \mathrm{MJ} / \mathrm{t}$ [18] (p. 16). Due to an enthalpy value of zero of pure substances, the enthalpy difference is $1327 \mathrm{MJ} / \mathrm{t}$ (cf. Figure 2). This corresponds to the theoretical minimum expenditure $C_{P h O}$.

The medium-frequency induction furnace is considered the most efficient furnace to achieve the defined utility, compared to cupola furnace or other induction furnaces [22] (p. 26). Hence, this technology is described for the theoretical case of the PhO. The following properties are required for the utility generated by the ideal minimum expenditure:

- No ohmic resistances of transformer, inverter, capacitor, coil, and power lines;

- No magnetic scattering or no magnetic resistance of the environment;

- No iron losses of the transformer and the coil;

- No friction due to coil vibrations (due to ideal fixing of the coil (rigid body) or friction coefficient equal to zero);

- No heat loss of the furnace (adiabatic crucible or zero melting time).

These are technically not feasible but can be regarded as the physical limit to which the technical improvements are approaching. On the basis of this, optimization possibilities can be derived.

The electrical energy, which amounts to $2339 \mathrm{MJ} / \mathrm{t}_{\mathrm{P}}$, is taken into account as the only energy input. The enthalpy of the coolant input is disregarded since it is a transit flow. The averaged efficiency of the transformer amounts to $98.5 \%$ and the one for the induction coil is $83.9 \%$. Converter, capacitor, and power lines have an overall efficiency of $94.4 \%$ [17]. The reciprocal value equals the $\mathrm{PhO}$ factor of each component.

The $\mathrm{PhO}$ factor of the induction furnace is calculated as the ratio of real resource input $C$ to the ideal minimum input $C_{P h O}$, referring to the system boundary in Figure 1. It amounts to approximately 1.76 , which means 1.76 times more energy is currently required than theoretically predicted. Thus, the theoretical energy-saving potential equals the loss, which 
amounts to $1012 \mathrm{MJ} / \mathrm{t}_{\mathrm{P}}$. Based on our calculations, the energy analysis of the induction furnace according to the PhO method is shown in Figure 4.

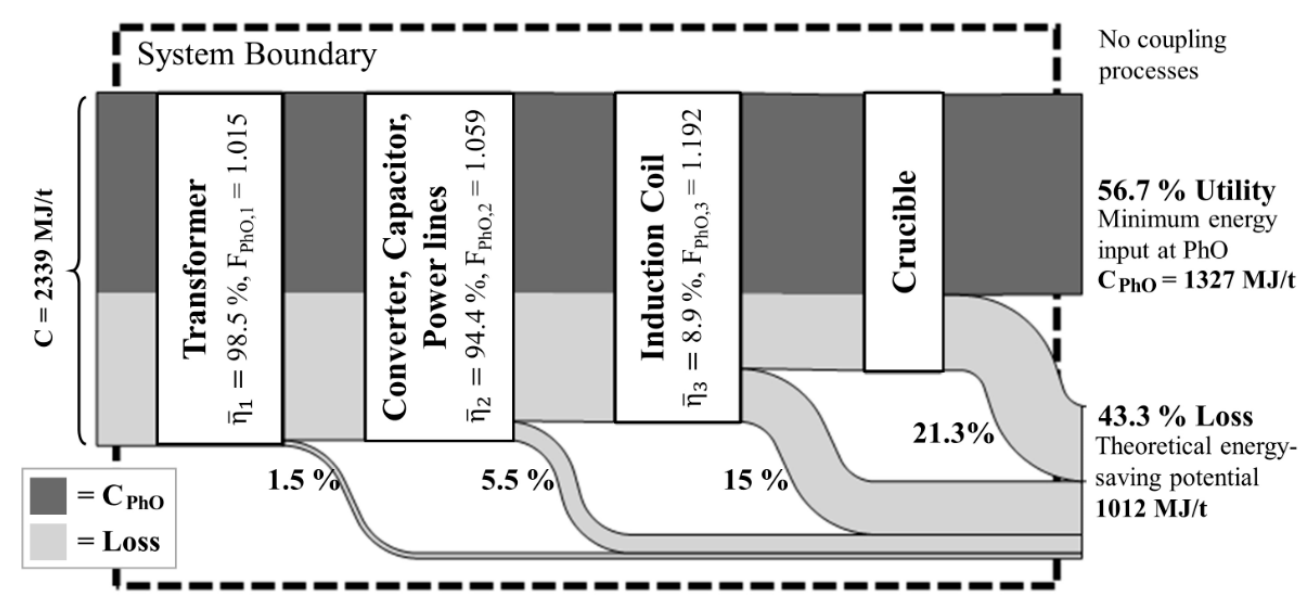

Figure 4. Sankey diagram of the energy flows of the induction furnace melting SG iron according to the physical optimum $(\mathrm{PhO})$ method.

\subsection{Method Comparison}

In this section, differences and intersections of the $\mathrm{PhO}$ method and exergy analysis are analyzed. The $\mathrm{PhO}$ is defined as the optimal, ultimate process that provides the starting point for the analysis. The exergy $B$, on the other hand, is a certain energy fraction that can be irreversibly converted into anergy $A$ by exergy destruction $E_{D}$. In contrast to the $\mathrm{PhO}$ method, the exergy analysis starts from the real process from whose analysis the theoretically avoidable losses can be derived. Thus, exergy destruction $B_{D}$ within the balance area and the exergy loss $B_{L}$ leaving the system unused become clear.

One goal of the exergy analysis and the PhO method is to reveal the physical limitations of the improvement measures. The exergetic optimum corresponds to a process that has no exergy destruction $B_{D}$ and no exergy loss $B_{L}$. This theoretical process with no exergy losses $B_{D}$ and $B_{L}$ represents an ultimate reference process similar to the PhO. However, in this study, the exergy analysis is more precise because the chemical composition of the environment and the exergy of the material flows are taken into account.

Regarding the analysis of the induction furnace, the difference between $C$ and $B_{\text {in }}$ results from the chemical exergy of the material input of carbon $(C)$ and $\mathrm{SiC}$, which is not considered within the de $\mathrm{PhO}$ method in this application example. Furthermore, different minimum energy demand was derived regarding $B_{P}$ compared to $C_{P h O}$. The difference has multiple reasons. Firstly, the PhO method assumes a physically optimal product made from ideal input materials, which results in another averaged heat capacity. Secondly, the exergy analysis regards the exergy of the product that has $100 \mathrm{~K}$ higher temperature than required according to the utility definition. Additionally, the product contains chemical exergy, which is disregarded by the $\mathrm{PhO}$ method as applied in this study. However, the most important reason is that the $\mathrm{PhO}$ method makes no explicit distinction between exergy and anergy. Within the $\mathrm{PhO}$ method, the minimum energy demand $Q_{P h O}$ is calculated as enthalpy difference despite the entropy increase during the isobaric change of state from $T_{1}$ above ambient temperature to a higher temperature [4] (p. 22). Thus, the enthalpy includes the anergy of $T_{a m b}\left(S_{2}-S_{1}\right)$, which was not considered in the scope of the PhO method in this study. In this case, however, it would be important to conclude that the $C_{P h O}$ must have this certain composition of anergy and exergy. Since electricity, which is pure exergy, is supplied to the furnace the minimum exergy expenditure is

$$
B_{\text {min }}=H_{2}-H_{1}-T_{a m b}\left(S_{2}-S_{1}\right) .
$$


This relation is illustrated in Figure 5 by means of the T-s diagram. The areas in the diagram below the isobar are named $a, b, c$, and $d$. Since the minimum energy consumption $C_{P h O}$ according to the PhO method is calculated as the enthalpy difference in this study, this corresponds to the sum of the areas a and b. According to Equation (6), the minimum exergy input is the enthalpy difference of the product in state 2 to state 1 (i.e., the sum of areas a and b) minus the entropy difference multiplied by the ambient temperature (i.e., minus area $b$ ). This gives a total of $(a+b)-b=a$. The area a thus corresponds to the minimum exergy input in the case of $\mathrm{PhO}$. Since the exergy analysis in this study is based on the real process, $T_{2}$ is equal to $1873 \mathrm{~K}$ and the exergy in the product is equal to the sum of the two areas a and c. The differing averaged heat capacities are neglected in this context.

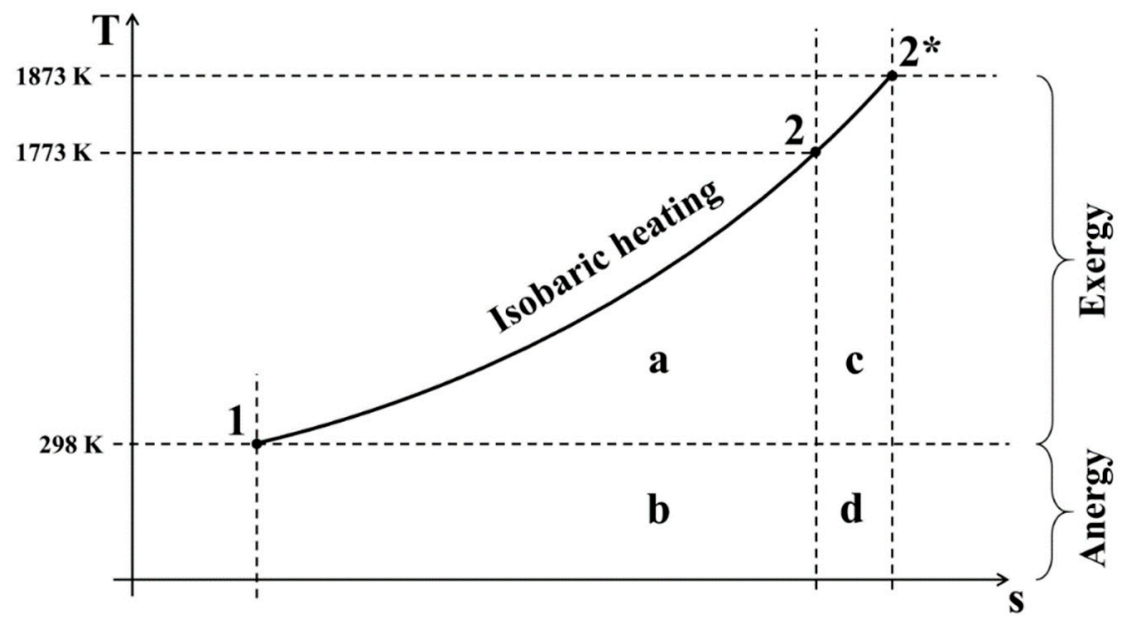

Figure 5. Simplified T-s diagram of the isobaric heating of SG iron from $T_{1}>T_{a m b}$ and illustration of the minimum energy demand $C_{P h O}$ as a plus b for heating to $1773 \mathrm{~K}$ (state 2 ) at $\mathrm{PhO}$ and the exergy of the product $B_{P}$ as a plus $\mathrm{c}$ for heating to $1873 \mathrm{~K}$ (state $2^{*}$ ) as in the real process.

To sum up, these differences between exergy analysis and the PhO method with regard to the analysis of the induction furnace are shown in Figure 6 by means of a Sankey diagram.

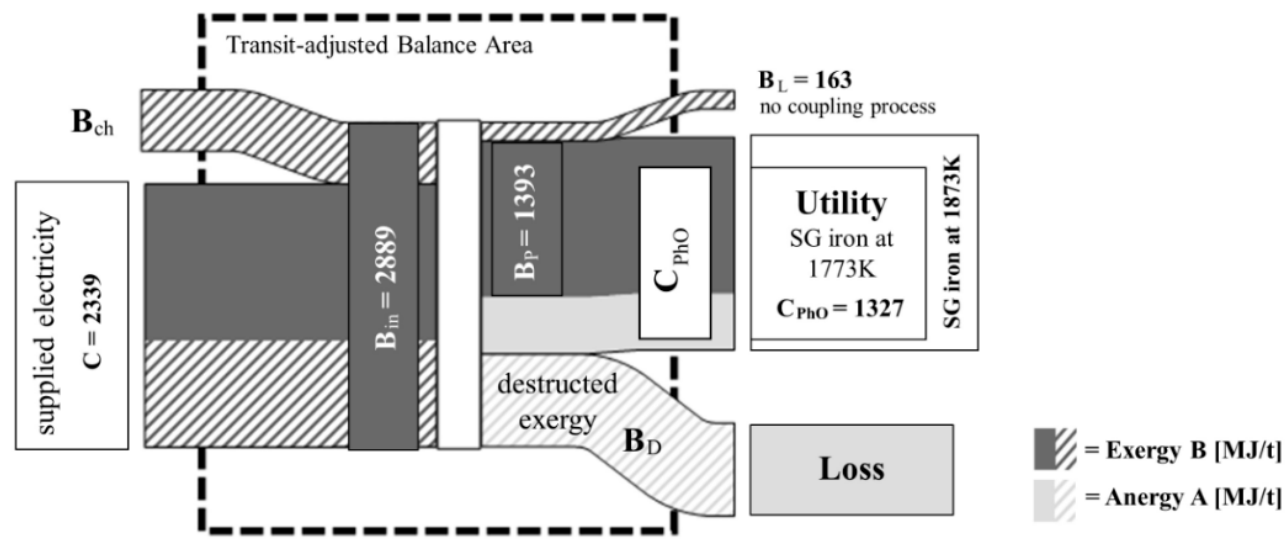

Figure 6. Correlations between exergy analysis and $\mathrm{PhO}$ method regarding the exergy and anergy flows $[\mathrm{MJ} / \mathrm{t}]$ of an induction furnace.

For the process-independent comparison of the two balancing approaches, the $\mathrm{PhO}$ energy flows are also analyzed by considering the exergy flows, although no exergy analysis is intended according to $[1,2,4]$. Deviations due to chemical exergy and the difference between exergy of the product and exergetic utility are neglected. 
In contrast to the exergy analysis, which considers only the exergy input as an expenditure, regarding the $\mathrm{PhO}$ method, anergy is in some cases considered as an expenditure or as part of the utility, e.g., the anergy fraction of the "ideal heat input $Q_{P h O}$ " for a hot water supply. Thus, "expended" anergy $A_{\text {in,exp }}$ has to be considered if it is defined by the framework condition that the energy input is supplied as heat.

Contrary to this, anergy as ambient heat is counted in some cases as "costless" ambient heat, which is used, e.g., for a heat pump. Regarding this case of a heat pump, free anergy $A_{\text {in, }, 0}$ enters the balance area and leaves it as anergy of the product $A_{P}$ in case heat is the utility.

Thus, for this comparison the anergy input $A_{\text {in }}$ can be divided into the "costless" ambient anergy $A_{i n, 0}$ on the one hand, and the anergy expenditure $A_{\text {in,exp }}$ as part of heat input on the other hand. Furthermore, in the case of heat as the utility, this utility can be described by a quantity of energy consisting of both exergy $B_{P}$ and anergy $A_{P}$. Hence, the anergy output $A_{\text {out }}$ is either the product-bound anergy $\mathrm{A}_{\mathrm{P}}$ in case of heat being the utility or, in the case of a Carnot process, emitted to the environment as $A_{\text {out,exp }}$ together with the destructed exergy $B_{D}$. The originally expended anergy $A_{\text {out,exp }}$ leaves the system "unnoticed" and separately from the utility. In the case of the Carnot process, however, this anergy $A_{\text {out, exp }}$ cannot be counted toward the losses either if the framework condition defines heat as the input and pure exergy $B_{P}$ as the utility. In general, the minimum energy expenditure $C_{P h O}$ according to the $\mathrm{PhO}$ method equals the sum of $B_{P}$ and $A_{\text {in,exp }}$. However, $A_{\text {in,exp }}$ appears to be a special case.

To sum up, Figure 7 shows the energy balance of an open system as a Sankey diagram. The balance is associated with exergy and anergy flows entering and leaving the system. Transit exergy $B_{\text {trans }}$ is theoretically led around the balance area and therefore subtracted from the balance. The PhO method as applied in this study neglects the transit flows. Transit anergy can be neglected since ambient heat is available unlimited and has no effect on the process.

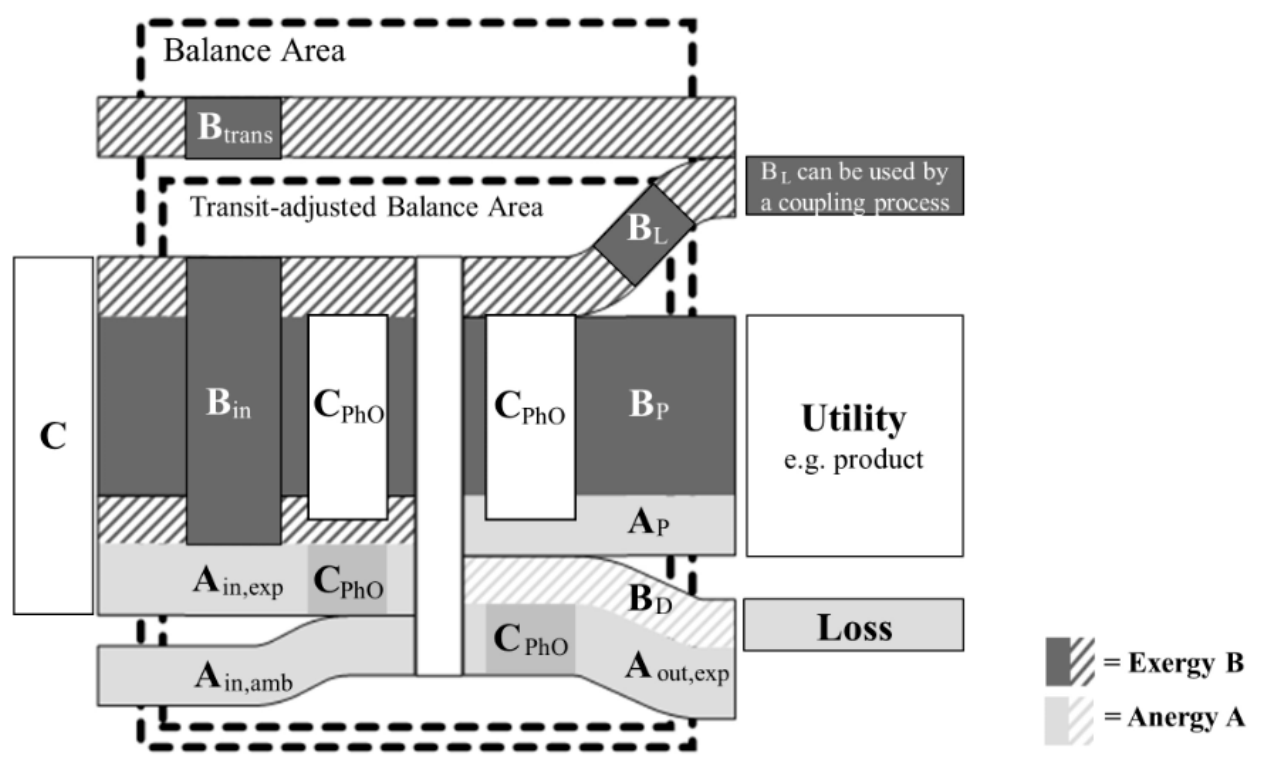

Figure 7. Energy balance of an open system examined by both exergy analysis and PhO method. While the $\mathrm{PhO}$ method regards the real energy expenditure $C$, the ideal minimum energy input $C_{\mathrm{PhO}}$ and losses and coupling processes, the exergy analysis goes further by explicitly dividing between exergy and anergy and, if necessary, considering transit flows.

The comparison makes clear that coupling processes are possible only when the exergy loss $\mathrm{B}_{\mathrm{L}}$ is greater than zero, which is not estimated within the PhO method as long as exergy is not used as a state variable within the PhO method, as in this study. Only the exergy analysis reveals whether and to what extent the losses can be used by coupling 
processes. An important result is that at least the losses must be analyzed exergetically if the potential for coupling processes is to be determined.

\section{Discussion}

This section provides a discussion of the assumptions made and compares the results of this study with those of previous studies. Furthermore, the differences and similarities found between the exergy analysis and the PhO method are discussed.

\subsection{Analysis of the Induction Furnace}

The physical exergy of the SG iron of $975 \mathrm{MJ} / \mathrm{t}$ at $1873 \mathrm{~K}$ is first compared with literature values. This result is based on a calculated heat capacity of $0.949 \mathrm{~kJ} / \mathrm{kg} / \mathrm{K}$ as the mean slope of the enthalpy curves by Hack [18] (pp. 11-17). On the contrary, Gonzales et al. [23] report physical exergy for liquid steel of $550 \mathrm{MJ} / \mathrm{t}$, and for hot metal, of $530 \mathrm{MJ} / \mathrm{t}$ at $1573 \mathrm{~K}$, and ambient pressure by using the specific heat capacities of $0.68 \mathrm{~kJ} / \mathrm{kg} / \mathrm{K}$ and $0.71 \mathrm{~kJ} / \mathrm{kg} / \mathrm{K}$, respectively. These values originate from Lally et al. [24] and refer to a 1010 carbon steel grade, which means the carbon content is significantly lower. Moreover, it is based on the simplifying assumption of the heat capacities being "constant functions of temperature outside of the two phase region" [24]. This may cause the deviation. Furthermore, Szargut et al. [7] (p. 113) provide a graph showing the correlation between the physical exergy of $\mathrm{Fe}-\mathrm{Fe}_{3} \mathrm{C}$ alloys depending on temperature and mass percentage of carbon. Accordingly, the physical exergy of cast iron with $3.6 \%$ carbon content is about $770 \mathrm{MJ} / \mathrm{t}$ at $1573 \mathrm{~K}$ and about $900 \mathrm{MJ} / \mathrm{t}$ at $1773 \mathrm{~K}$, which approximately corresponds to the values calculated in this study.

A major point for discussion regarding the exergy analysis is transit flows. It must be precisely examined which exergy flows are regarded as transit flows because this has crucial effects on exergetic efficiency. The more transit flows that are included, the higher is the calculated efficiency. Within the scope of this analysis, the majority of the chemical exergy of the input materials was treated as transit exergy since the chemical structure of these materials changes only to a minor extent. In order to reduce the uncertainty of the assumption to transit flows, we recommend regarding the exergetic efficiency and the entire exergy balance.

Furthermore, the example of the induction furnace shows the importance of the definition of the utility and the system boundary. If the utility is defined as the exergy content of the product, it will not be clear, for example, that the product is heated to a temperature of $1873 \mathrm{~K}$, which is more than is physically necessary to achieve the required product quality. The foundry under consideration heats up to $1873 \mathrm{~K}$ to ensure a sufficiently high temperature during an unusually long retention time after the melting process. A distinction should therefore be made, where appropriate, between the exergy utility and the exergy of the product. Another difference to be further analyzed is whether the system undergoes exergy loss or destruction. In addition, the definition of the system boundaries and framework conditions is crucial. If the balance area would be extended to the finished casting at ambient temperature, waste heat in the $\mathrm{PhO}$ could be completely recovered or used externally. In this case, it could be argued that the minimum effort would be $0 \mathrm{MJ} / \mathrm{t}$ due to recovery or allocation.

For a more comprehensive comparison between the two methods regarding more technologies and processes, further investigation is required. Among others, a more detailed study of the handling of waste heat and cooling of initially heated materials as the complement to the induction furnace would be helpful since the utility definition and framework conditions are not entirely clear.

\subsection{Method Comparison}

Although both methods show the physical limits of efficiency improvements, some differences became apparent regarding the evaluation of inventoried flows, the calculation of 
minimum expenditure, and the maturity and complexity of the methods. Accordingly, there are different areas of application for the two methods.

The PhO method is intended for the separate evaluation of different levels of inventoried flows. This concerns energy, resources, and information [2] (p. 56). In this context, however, no approach has yet been provided as to how the different levels can be evaluated against each other. A combined approach to evaluate energy and material efficiency is so far only possible by means of exergy analysis.

Moreover, the $\mathrm{PhO}$ method does not explicitly distinguish between exergy and anergy. Describing the minimum energy input as "ideal heat input" calculated by the enthalpy difference, as intended in the VDI guideline, is less informative than an exergy calculation since the energy quality does not become clear and any heat could theoretically be provided by means of upgrading anergy by pure exergy.

The application of the PhO method in this study comprises approximately the thermodynamic and exergy correlations but neglects the chemical composition of the material flows and the environment. In some cases, this can lead to wide variations from the exergy analysis. In this study, the exergy analysis provides a more precise result regarding energy and material flows. An exergy analysis to be recommended if chemical exergy is a crucial factor and chemical material flow data is available. In addition, it is advantageous in order to evaluate work and heat uniformly. Moreover, the theoretical potential for coupling processes can be identified by distinguishing between exergy destruction and exergy loss.

The calculation of the minimum effort is generally based on the utility definition. In the case of the exergy analysis, we define the utility as the exergy of the product according to Szargut et al. [7]. Instead, the PhO method considers the benefit of the reference product as the SG iron at $1873 \mathrm{~K}$ since among others Dötsch [10] reports that this is usually sufficient. These different assumptions regarding the utility definition should be considered. The exergy analysis could also be performed by defining the utility as the exergy of the SG iron at $1773 \mathrm{~K}$ under PhO conditions since the exact description of utility and boundary conditions are not methodologically specified.

In order to determine the theoretical limit value of the expenditure for the defined utility using the $\mathrm{PhO}$ method, it must be possible to quantify the utility and allocate a minimum amount of resources. As the exergy analysis is mostly based on a real process, the analysis can be performed for every process. However, the exergy efficiency can only be calculated if the exergy utility is quantifiable.

Furthermore, it should be considered that the $\mathrm{PhO}$ method was developed by Volta [1] a few years ago, and the development of guidelines and systematics is not yet finished. A draft for a new guideline of the Association of German Engineers (VDI) is currently available [4]. The exergy analysis is well developed and mature. Moreover, the term optimum can be misleading because in the context of the $\mathrm{PhO}$ method it does not describe the compromise of two opposing parameters but rather the unreachable limit value or ideal. Another important difference between the two methods is the complexity of the methods. Therefore, the time required to carry out the PhO method in this study is lower than for the exergy analysis. On the other hand, the results can be less precise as long as exergy is not used as a state variable within the PhO method, as in this study.

An advantage of the $\mathrm{PhO}$ method compared to the exergy analysis is that fluctuations in ambient temperature and pressure can be taken into account more easily as long as the energy is used as a state variable. This can result in a temperature or pressure-dependent value for the $\mathrm{PhO}$, enabling the efficiency to be measured using the $\mathrm{PhO}$ factor independently of these fluctuations. The consideration of tabulated chemical exergy that always refers to standard ambient conditions makes this more difficult within the exergy analysis.

Either way, both methods contribute significantly to the appropriate target definition for efficiency measures. This will make it possible to identify at an early stage the extent of the necessity for complementary measures to make production more environmentally friendly, e.g., by using renewable energies. For example, induction furnaces could be operated almost entirely with electricity from renewable energy sources [25]. 


\section{Conclusions and Outlook}

Due to the interactions between the individual efficiency measures, the total energy saving potential cannot be derived from the individual potentials. A crucial advantage of the limit value-oriented assessment methods is that the theoretical potential can be shown and used to estimate the current technical potential. Regarding the energy flows, the induction furnace under consideration currently requires 1.76 times more energy than theoretically predicted to melt SG iron. Similarly, the exergy analysis results in an exergy efficiency of $48 \%$, which, however, depends strongly on the definition of transit exergy.

The comparison of the two methods demonstrates that the exergy analysis is much more complex and accurate than the $\mathrm{PhO}$ method regarding the assessment of material flows, especially in the case of chemical reactions taking place and as long as exergy is not used as a state variable within the PhO method, as in this study. The material and energy flows can be evaluated in combination by quantifying by means of exergy units. The chemical exergy of the material flows is also taken into account in relation to the chemical composition of the environment. With the PhO method as applied in this study-e.g., apart from the calorific values-the chemical exergy of the materials toward the environment is not taken into account due to the chemical composition of the environment being neglected. By distinguishing between exergy destruction and exergy loss, the theoretical potential for coupling processes can be identified by means of exergy analysis. Only with exergy analysis, the exergy content of the losses and irreversibility to be avoided in the system become clear. In some cases, it should be considered which exergy fraction must be included in the minimum energy input according to the $\mathrm{PhO}$ method. For example, the "ideal amount of heat" for heating cannot be ambient heat but must contain a certain amount of exergy, which only becomes clear by means of the exergy analysis.

Depending on the framework conditions and the desired level of detail of the efficiency assessment, it must be decided which method with what accuracy is to be applied. If material and energy are to be evaluated in combination, an exergy analysis can be used for more extensive investigations. The calculation of the minimum energy requirement can significantly support the appropriate definition of the efficiency goals. Both methods can be suitable for this purpose.

In the context of the Paris Climate Agreement, increasing resource efficiency is regarded as an important measure. Limit-value-oriented assessment methods can contribute to determining the extent to which it is theoretically possible to limit the climate impact of increasing resource demand by increasing efficiency. These methods demonstrate that this is only possible to a limited extent, and the necessity for further measures such as renewable energy, sufficiency, and consistency options can be quantified. Both the PhO method and the exergy analysis can make a decisive contribution to this strategy. Depending on the goal and scope, there are different areas of application for the two methods.

Author Contributions: Conceptualization, P.M.W., P.R., and J.W.; methodology, P.M.W., P.R., and J.W.; validation, P.M.W.; formal analysis, P.M.W.; investigation, P.M.W.; data curation, P.M.W. and J.W.; writing-original draft preparation, P.M.W.; writing-review and editing, P.M.W. and P.R.; visualization, P.M.W.; supervision, P.R. and J.W.; project administration, P.R.; funding acquisition, P.M.W. and P.R. All authors have read and agreed to the published version of the manuscript.

Funding: This research was funded by the Graduate and Research School for Energy Efficiency Stuttgart, GREES PhD scholarship and the Open Access Publication Fund of the University of Stuttgart.

Institutional Review Board Statement: Not applicable.

Informed Consent Statement: Not applicable.

Data Availability Statement: No new data were created or analyzed in this study. Data sharing is not applicable to this article. 
Acknowledgments: The authors gratefully acknowledge the support of Bosch Energy and Building Solutions $\mathrm{GmbH}$, in particular for enabling the data collection.

Conflicts of Interest: The authors declare no conflict of interest. The funders had no role in the design of the study, in the collection, analyses, or interpretation of data, in the writing of the manuscript, or in the decision to publish the results.

\section{Abbreviations}

Abbreviations

PhO physical optimum

PIOT physical input-output table

SG iron spheroidal graphite cast iron

VDI Verein Deutscher Ingenieure

Symbols

$\begin{array}{ll}\text { A } & \text { anergy [J] } \\ \text { B } & \text { exergy [J] } \\ \text { C } & \text { amount of a resource }(\text { e.g., energy [J]) } \\ \text { c } & \text { heat capacity }[\mathrm{kJ} /(\mathrm{kgK})] \\ \mathrm{f} & \text { factor }[-] \\ \mathrm{H} & \text { enthalpy }[\mathrm{J}] \\ \mathrm{p} & \text { pressure }[\mathrm{Pa}] \\ \mathrm{Q} & \text { heat }[\mathrm{J}] \\ \mathrm{S} & \text { entropy }[\mathrm{J} / \mathrm{K}] \\ \mathrm{T} & \text { temperature }[\mathrm{K}] \\ \mathrm{V} & \text { volume }\left[\mathrm{m}^{3}\right] \\ \mathrm{W} & \text { work }[\mathrm{J}] \\ \mathrm{x} & \text { mass fraction }[\mathrm{kg} / \mathrm{kg}] \\ \mathrm{y} & \text { mole fraction }[\mathrm{mol} / \mathrm{mol}] \\ \zeta & \text { exergy efficiency }[\%]\end{array}$

Subscripts

$\mathrm{amb}$ ambient (reference state, components)

ch chemical

D internal loss, destruction

el related to electricity

$\exp$

i component, parameter

in input

kin kinetic

L external loss

mag related to magnetism

mech mechanical

out output

$\mathrm{P}$ product

ph physical

PhO physical optimum

pot potential

th thermal

trans transit

\section{Appendix A}

Table 1 presents the data and relations of the exergy analysis. The data on chemical exergy originates from Szargut et al. [7]. Moreover, the data on heat capacity are obtained from the VDI Heat Atlas [21], except the heat capacity of SG iron. The mass and energy flows and temperatures are listed in the physical input-output table in Section 2.3 (cf. Table 2). 


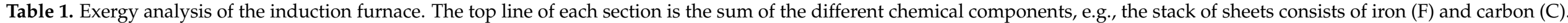

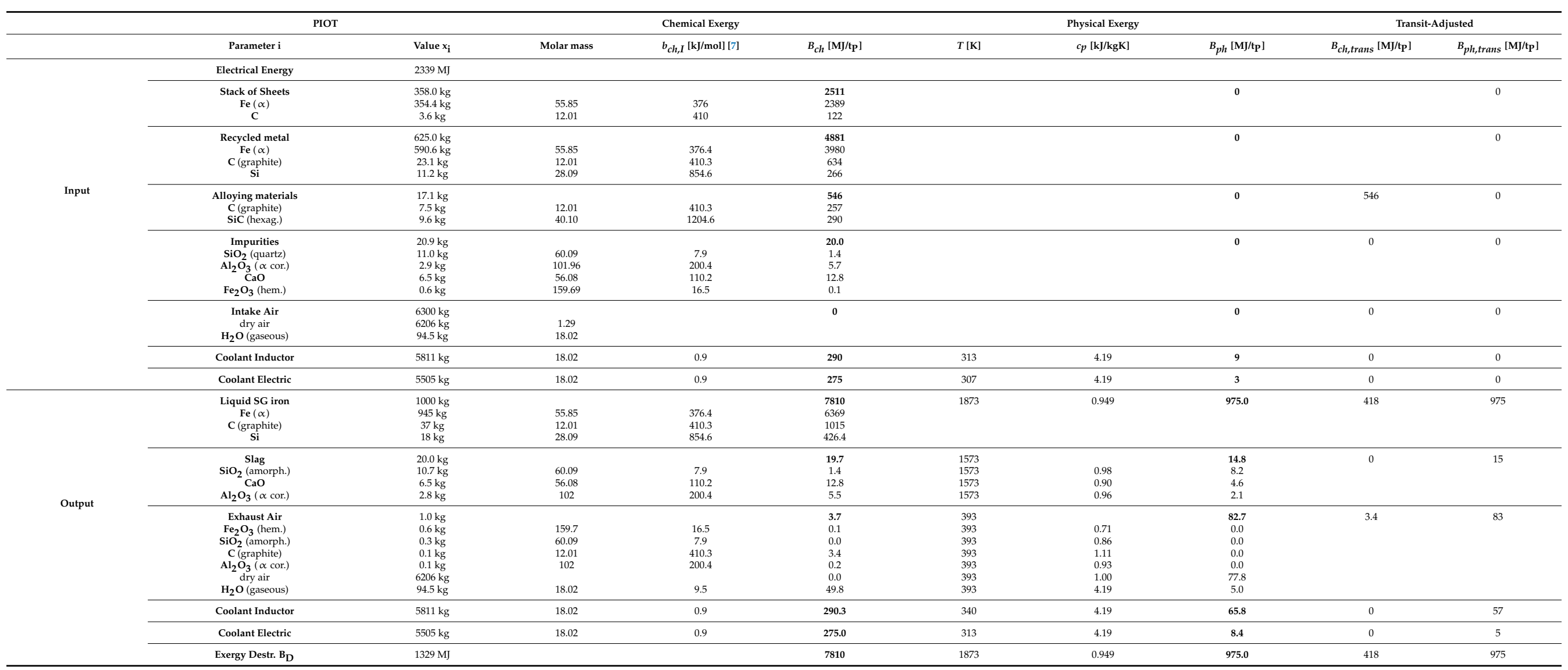




\section{References}

1. Volta, D. Das Physikalische Optimum als Basis von Systematiken zur Steigerung der Energie- und Stoffeffizienz von Produktionsprozessen. Ph.D. Thesis, Universitätsbibliothek Clausthal, Technische Universität Clausthal, Clausthal-Zellerfeld, Germany, 2014.

2. Keichel, C. Methode der Grenzwertorientierten Bewertung. Ph.D. Thesis, Universitätsbibliothek Clausthal, Technische Universität Clausthal, Clausthal-Zellerfeld, Germany, 2017.

3. Beckmann, N. Wechselwirkungsanalyse Zwischen dem Physikalischen Optimum, dem Betriebswirtschaftlichen Optimum und dem Carbon-Footprint-Optimum (PhO-BwO-CFO). Ph.D. Thesis, Universitätsbibliothek Clausthal, Technische Universität Clausthal, Clausthal-Zellerfeld, Germany, 2017.

4. Sankol, B.; Keichel, C.; Volta, D.; Pauksztat, A.; Kohn, D.; Kretschmer, L.; Meyer, S.; Girbig, P.; Kastner, H.-J. (Eds.) Verein Deutscher Ingenieure. Bewertung von Energie- und Stoffeffizienz Methodische Anwendung des Physikalischen Optimums; Beuth Verlag GmbH: Berlin, Germany, 2019; ISC 27.015 (4663-1).

5. Szargut, J. International progress in second law analysis. Energy 1980, 5, 709-718. [CrossRef]

6. Gutowski, T.G.P.; Sekulić, D.P. Thermodynamic Analysis of Resources Used in Manufacturing Processes. In Thermodynamics and the Destruction of Resources; Bakshi, B.R., Sekulić, D.P., Gutowski, T.G.P., Eds.; Cambridge University Press: Cambridge, UK, 2011; ISBN 9780511976049.

7. Szargut, J.; Morris, D.R.; Steward, F.R. Exergy Analysis of Thermal, Chemical and Metallurgical Processes; Hemisphere Publ. Corp: New York, NY, USA, 1988; ISBN 9780891165743.

8. Fratzscher, W.; Brodjanskij, V.M.; Michalek, K. Exergie. Theorie und Anwendung, 1st ed.; Deutscher Verlag für Grundstoffindustrie: Leipzig, Germany, 1986; ISBN 3-342-00091-0.

9. Riedl, K. Exergetische und Exergoökonomische Bewertung von Verfahren der Energie- und Stoffwandlung. Ph.D. Thesis, Martin-Luther-Universität Halle-Wittenberg, Merseburg, Germany, 2007.

10. Dötsch, E. Induktives Schmelzen und Warmhalten. Grundlagen, Anlagenaufbau, Verfahrenstechnik, 3rd ed.; Vulkan Verlag: Essen, Germany, 2019; ISBN 9783802731075.

11. Dötsch, E. Induktionsofentechnologie und Energieeffizienz. GIESSEREI 98 2011, 6, 158-170.

12. ETSU. Efficient Melting in Coreless Induction Furnaces. Good Practice Guide 50. 2000. Available online: https://lists.man.lodz.pl/ pipermail/odlew-pl/2012/10/att-0003/guide_coreless_induction_furnaces.pdf (accessed on 12 October 2020).

13. Neumann, F. Gußeisen. Schmelztechnik, Metallurgie, Schmelzbehandlung, 2nd ed.; Expert-Verl.: Renningen-Malmsheim, Germany, 1999; ISBN 3816917283.

14. Schwanke, W. Schmelzen in Hochleistungsinduktionsöfen. In Elektrische Prozeßwärme für Aluminium, Gußeisen, Stahl: Tagung Essen, July 1993, 1st ed.; VDI, Ed.; VDI-Verl.: Düsseldorf, Germany, 1993; pp. 97-100. ISBN 3-18-091057-7.

15. Wenzel, P. Exergetische Analyse und Physikalisches Optimum zur Bewertung und Steigerung der Ressourceneffizienz am Beispiel Eines Mittelfrequenzofens. Master's Thesis, Universität Stuttgart, Stuttgart, Germany, 2019.

16. Frenzel, P. Bewertung von Syntheserouten auf Basis von Exergiebilanzen. Ph.D. Thesis, Technische Hochschule Aachen, Aachen, Germany, 2014.

17. Trauzeddel, D. Spezielle Anwendungen der Induktiven Schmelz- und Gießtechnik. Einsatzgebiete-Anlagenbau-Prozesstechnik, 1st ed.; Vulkan: Essen, Germany, 2018; ISBN 978-3-8027-3093-1.

18. Hack, K. Stoffwerte von Metallen und Berechnung von Wärmebilanzen. In Praxishandbuch Thermoprozess-Technik, 1st ed.; Starck, A.V., Mühlbauer, A., Kramer, C., Eds.; Vulkan-Verl.: Essen, Germany, 2003; ISBN 3-8027-2923-4.

19. Trauzeddel, D.; Otto Junker GmbH, Simmerath, Germany. Personal communication, 6 May 2019.

20. Neumann, F.; Schneider, W.-D.; Herfurth, K. Der Schmelzprozess für Eisenguß (GG/GGG/GT) aus der Sicht der Umwelt- und Klimabelastung in Zusammenhang mit dem Energieverbrauch. In Elektrische Prozeßwärme für Aluminium, Gußeisen, Stahl: Tagung Essen, July 1993, 1st ed.; VDI, Ed.; VDI-Verl.: Düsseldorf, Germany, 1993; ISBN 3-18-091057-7.

21. Verein Deutscher Ingenieure. VDI-Wärmeatlas, 11th ed.; Springer: Berlin/Heidelberg, Germany, 2013; ISBN 978-3-642-19980-6.

22. Svehla, J.; Krutzler, T.; Schindler, I. Stand der Technik der Österreichischen Gießereien. Gesetzliche Rahmenbedingungen, Technische Möglichkeiten und Gießereibetriebe in Österreich. 2012. Available online: https://www.umweltbundesamt.at/fileadmin/site/ publikationen/REP0389.pdf (accessed on 12 October 2020).

23. Gonzalez Hernandez, A.; Paoli, L.; Cullen, J.M. How resource-efficient is the global steel industry? Resour. Conserv. Recycl. 2018, 133, 132-145. [CrossRef]

24. Lally, B.; Biegler, L.; Henein, H. Finite difference heat-transfer modeling for continuous casting. MTB 1990, 21, 761-770. [CrossRef]

25. Bosse, M.; Frost, E.; Hazrat, M.; Riemeier, J.-M.; Wolff, H. Ermittlung von Branchenspezifischen Potentialen zum Einsatz von Erneuerbaren Energien in Besonders Energieintensiven Industriesektoren am Beispiel der Gießerei-Industrie. UBA-FB 00. 2013. Available online: https://www.bmu.de/fileadmin/Daten_BMU/Pools/Forschungsdatenbank/fkz_3712_44_347_erneuerbare_energien_ bf.pdf (accessed on 12 January 2020). 